International Conference on Business Research

University of Moratuwa, Moratuwa, Sri Lanka

June 13, 2018, 49-58.

DOI: https://doi.org/10.31705/ICBR.2018.7

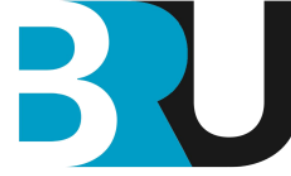

BUSINESS RESEARCH UNIT

FACULTY OF BUSINESS

UNIVERSITY OF MORATUWA

\title{
Facilities management value addition in enhancing business profitability in hotel industry in Sri Lanka
}

\author{
T. Nishanthy*, S. D. A. Soorige and H. W. T. P. Rathnasiri \\ Department of Building Economics, Faculty of Architecture, University of \\ Moratuwa, Sri Lanka
}

Facilities management (FM) is a globally established profession which is constantly growing. It involves in the organization's growth by providing the best support services to the organization's core business activities. FM is not only considered as a profession which delivers support services but a profession which is necessary for the organization to run a smooth operation while improving the productivity, market share, profitability with added value to the organization. However, though FM has been perceived as an important profession, the use of FM is still not well established in the Sri Lankan context to gain integrated value addition for business. Therefore, this study aimed to explore the Value Addition from Facilities Management in Enhancing the Business Profitability focusing in the hotel industry in Sri Lanka. A comprehensive literature review was carried out first discussing on hotel business, business profitability, and criteria of business profitability, FM functions, and contribution of FM for the business profitability. A quantitative mixed research approach was followed by a detailed questionnaire survey and case study interviews. Data analysis technique of the questionnaire survey involved RII method. Findings of the questionnaire survey consisted of Ten (10) most significant factors affecting business profitability and eleven (11) most significant FM functions which enhance the profitability of hotel sector. Findings of the case study revealed the way that identified FM functions which are involved in creating a value addition to enhance the business profitability in hotel sector.

Keywords: business profitability, facilities management, FM function, hotel industry, value addition 


\section{Introduction}

FM is identified as a distinct function of an organization that is related to the organization's needs (Kasim \& Hudson, 2006). The term FM often relates to the work environment and the physical assets of the organization (Edwards, 2012). Further to Edwards (2012), FM is a profession of interconnecting standard procedures to produce an effective work environment to support the core objective of the business. It helps to accomplish the expectations of a particular business organization towards the business profitability (Barrett \& Baldry, 2003). As mentioned by Coenen, Alexander and Kot (2013), FM supports to enhance the organizations with an added value while optimising the costs and maximising the quality of final outcome. FM organizations cooperate and comply FM services and FM solutions with the requirements and goals of businesses for the proper value added FM services delivery (Coenen, Alexander, \& Kot, 2013). Further, Bontis, Janošević, and Dženopoljac (2015), have mentioned that there is a huge room to improve the value addition in hotel sector by efficient use of human, physical and structural capital which in turn leads to enhance the employee productivity and business profitability. Further, from FM point of view, hotel industry has been perceived where there is a wide scope for strategic view of FM (Penny, 2012). As explained by Amaratunga, Baldry and Sarshar (2000), the need of FM for buildings is still not actually determined in Sri Lanka where there are number of opportunities to enhance operation and maintenance of buildings. Thus, this research is aimed to identify the value addition from facilities management in enhancing the business profitability in hotel sector in Sri Lanka.

\section{Literature Review}

\subsection{Business profitability}

"Profitability is the ability of a given investment to earn a return from its use". It is regarded as a measure of efficiency which can lead to a greater return in future as well. Profitability is one of key performance indicator which indicates the efficiency of a particular business (McDonald, 1999).

\subsection{FM functions}

FM department is responsible to manage the infrastructure facilities and property in order to achieve optimum productivity, constant quality improvement, cost reduction and risk minimization and ultimately improved value for money and profitability (Jensen, et al., 2012).Effective facilities management focuses on corporate asset management to add value to core business activities, provide enabling environment for offering superior service quality in support of business operations (Barrett \& Baldry, 2003). FM also aims to sharpen the corporate business image and the productivity of the organization through facilities improvement, and enhancement of operational efficiency and effectiveness. 
2.3 Contribution of facilities management and strategies to be followed for the business profitability in hotel industry - value addition in FM functions

FM, like other business functions, aims at creating advantages to the business. Barrett and Baldry (2003) mention that FM leads and should lead to the reduction of costs, a better quality of products and services, an effective organization, customer satisfaction, increase profitability and competitive advantage. Besides, FM can contribute cost control, support of productivity, risk control, increase satisfaction, support image, and increase sustainability. There is clear preference and need for cost reductions and cost control in FM (Bagshaw \& Peters, 2015). These aims can also be named as the advantages that effective FM brings to a hotel.

FM in hotels expected to maintain quality services efficiently and effectively through the optimized performance of the systems usually installed including HVAC, ventilations, fire system, transportation system, catering, lightning, plumbing and drainage, laundry and other support services (Jensen \& van der Voordt, 2015). The performance and productivity of working environment is controlled directly by FM employed in Hotels. It also satisfies the customers' needs and expectations while operating hotel facilities effectively. Reviewing customer complaints to understand the behaviour of customers, providing reliable support services by applying the total quality techniques to improve quality, add value and reduce the risks are strategies under the purview FM (Jensen, et al., 2012). Moreover, holistic and strategic approach of FM can add value to assets by managing building services in a structured manner (Durodola, Ayedun \& Onipede, 2012).

\section{Research method}

A quantitative first mixed research approach was followed where both quantitative and qualitative approaches were utilised to identify the value addition of FM to enhance the business profitability in hotel sector. The quantitative approach was first used since it was required to quantify the relative importance of factors affecting the profitability and profit related facilities management functions to fulfil the first few objectives. Then the qualitative approach was utilised since there was a need to study how selected FM function supports to enhance the business profitability which was a subjective assessment based on attitudes and opinions of respondents in the hotel industry. Therefore, the qualitative approach was utilised to cover respective objectives.

Questionnaire survey and semi structured interviews were used as two separate techniques to collect data under this approach. As the first method, questionnaire survey was conducted first including the business profitability factors and FM functions identified from the literature. It was used as the most applicable data collection method to verify the factors (profitability criteria and FM functions) and identify if other such factors. To conduct the survey, hotels certified for three-star and above were considered which have been registered in tourist board of Sri Lanka. Accordingly, 40 number of hotels were selected through convenience sampling method and questionnaires were distributed for $40 \mathrm{FM}$ professionals employed in hotels. 
However, 37 answered questionnaires were received and the findings of the questionnaire survey were analysed using Relative Important Index (RII) method to identify the most significant factors and FM functions in relation to the hotel sector. Subsequently, the identified factors were qualitatively analysed across three case studies conducting semi structured interviews to identify how FM functions help to enhance the business profitability in hotel sector. The selected cases were five-star certified hotels located in Colombo area. The interviews were conducted with five key participants of the hotel including top management representative, chief engineer, front office manager, human resource manager and the finance manager.

\section{Data Analysis}

\subsection{Findings of questionnaire analysis}

Factors affecting business profitability. Identified factors for business profitability through literature were analysed from the questionnaire survey using RII method to recognise the most significant factors which relevant for the hotel sector to enhance business profitability. The factors which given values more than 0.8 were considered as the most significant factors according to the Likert scale (1- not important ,2-less important,3- medium important ,4- important, 5- most important) as indicated in Table 1.

Table 1. Factors affecting business profitability

\begin{tabular}{lcc}
\hline \multicolumn{1}{c}{ Criteria } & RII & Rank \\
\hline Management (Vom Brocke \& Grob, 2010) & 0.99 & 1 \\
Operational effectiveness (Andrews, 2013). & 0.99 & 1 \\
Financial plan (Myeda, 2012) & 0.98 & 2 \\
Employee satisfaction (Coenen, Alexander \& Kot, 2013) & 0.98 & 2 \\
Growth (bagshaw \& peters, 2015) & 0.98 & 2 \\
Degree of competition (Coenen, Alexander \& Kot, 2013) & 0.97 & 3 \\
Relative cost & 0.97 & 4 \\
productivity (Yazdanfar, 2013) & 0.96 & 5 \\
The strength of demand & 0.95 & 6 \\
Objective of firms (Vom Brocke \& Grob, 2010) & 0.94 & 7 \\
The state of economy & 0.89 & 8 \\
Firm size & 0.87 & 10 \\
\hline
\end{tabular}

FM functions. The FM functions reviewed from the literature were analysed through the survey to identify the most significant FM functions which directly address the business profitability. Accordingly, following results were achieved from the analysis. The FM functions which given RII values more than 0.8 were selected as most important FM functions which enhance the business profitability as demonstrated in Table 2 . 


\subsection{Findings of case study analysis}

The purpose of RII method was to identify the most significant factors affecting business profitability in hotel sector and FM functions. After the quantitative analysis, case studies were conducted using five interviews to review how each FM function supports to enhance the business profitability by affecting for each profitability factor.

Table 1. Ranking of facilities management functions

\begin{tabular}{llc}
\hline Facilities management functions & RII & Rank \\
\hline Operational management (Padavano, 2005) & 0.974 & 1 \\
Maintenance management (Jones \& Lockwood, 1989) & 0.968 & 2 \\
Energy management (Jensen \& van der Voordt, 2015) & 0.955 & 3 \\
Waste management & 0.942 & 4 \\
House keeping & 0.923 & 5 \\
Procurement and tendering (Brown, Hinks, \& Sneddon, 2001. & 0.903 & 6 \\
Space and work place planning (Smith, 2011) & 0.890 & 7 \\
Risk management (Atkin \& Brooks, 2005) & 0.884 & 8 \\
Quality management (Pitt \& Goyal, 2004) & 0.877 & 9 \\
Emergency preparedness (Chotipanich, 2004) & 0.832 & 10 \\
Security-fire, security system (Barrett \& Baldry, 2003). & 0.800 & 11 \\
\hline
\end{tabular}

4.3. Most important FM functions which contributes to the business profitability in hotel sector

Findings of the case studies indicated which FM function relates to each profitability factor and how each FM function could support to enhance the business profitability in hotels across each factor. At the same time, the strategies of each FM function which influence profitability factors is further explained under this section as identified from the findings 'of interviews. Table 3 presents the FM functions and factors influenced by each function which ultimately leads to enhance the business profitability in hotel sector.

Operational management and maintenance management. According to the respondent's results, by implementing Just in Time as an operational strategy, the organization can eliminate waste and minimize inventories. Besides, Defect Preventive Program helps to reduce and cut down unnecessary costs, indirect labour cost, warehouse cost and step up time in maintenance activities engaged in hotel. Conversely, by enhancing frequency of maintenance, the organization can improve the life cycle time of an asset, reduce the breakdown/ repair situations, maintenance cost, unexpected spare part requirement cost, extra workforce cost, etc. 
Table 3. FM functions and factors influenced by FM functions

\begin{tabular}{|c|c|c|c|}
\hline \multirow[t]{2}{*}{ FM function } & \multicolumn{3}{|c|}{ Factors affecting business profitability } \\
\hline & Case 1 & Case 2 & Case 3 \\
\hline $\begin{array}{l}\text { Operational } \\
\text { management }\end{array}$ & $\begin{array}{l}\text { Operational } \\
\text { effectiveness, relative } \\
\text { cost, growth, } \\
\text { productivity, } \\
\text { management, firm } \\
\text { objectives }\end{array}$ & $\begin{array}{l}\text { Operational } \\
\text { effectiveness, relative } \\
\text { cost, growth, } \\
\text { productivity, firm size, } \\
\text { Financial plan, growth, } \\
\text { firm objectives }\end{array}$ & $\begin{array}{l}\text { Firm objectives, } \\
\text { management, } \\
\text { productivity, cost, } \\
\text { growth, operational } \\
\text { effectiveness, } \\
\text { employee } \\
\text { satisfaction }\end{array}$ \\
\hline $\begin{array}{l}\text { Maintenance } \\
\text { management }\end{array}$ & $\begin{array}{l}\text { Management, } \\
\text { productivity, cost, } \\
\text { growth, operational } \\
\text { effectiveness, } \\
\text { employee satisfaction, } \\
\text { firm objectives }\end{array}$ & $\begin{array}{l}\text { Management, } \\
\text { productivity, cost, } \\
\text { growth, operational } \\
\text { effectiveness, financial } \\
\text { plan, firm objectives }\end{array}$ & $\begin{array}{l}\text { Management, cost, } \\
\text { degree of } \\
\text { competition, } \\
\text { operational } \\
\text { effectiveness, state } \\
\text { of economy, growth, } \\
\text { firm objectives }\end{array}$ \\
\hline $\begin{array}{l}\text { Energy } \\
\text { management }\end{array}$ & $\begin{array}{l}\text { Management, cost, } \\
\text { degree of competition, } \\
\text { operational } \\
\text { effectiveness, state of } \\
\text { economy, growth, } \\
\text { firm objectives }\end{array}$ & $\begin{array}{l}\text { Degree of competition, } \\
\text { operational } \\
\text { effectiveness, cost, } \\
\text { financial plan, firm } \\
\text { objectives }\end{array}$ & $\begin{array}{l}\text { Firm objectives, } \\
\text { management, cost, } \\
\text { state of economy, } \\
\text { operational } \\
\text { effectiveness, cost }\end{array}$ \\
\hline $\begin{array}{l}\text { Waste } \\
\text { management }\end{array}$ & $\begin{array}{l}\text { Management, cost, } \\
\text { state of economy, } \\
\text { operational } \\
\text { effectiveness, } \\
\text { employee satisfaction, } \\
\text { firm objectives }\end{array}$ & $\begin{array}{l}\text { Management, } \\
\text { productivity, cost, } \\
\text { growth, operational } \\
\text { effectiveness, } \\
\text { employee satisfaction, } \\
\text { firm objectives }\end{array}$ & $\begin{array}{l}\text { Management, cost, } \\
\text { state of economy, } \\
\text { operational } \\
\text { effectiveness, } \\
\text { employee } \\
\text { satisfaction, firm } \\
\text { objectives }\end{array}$ \\
\hline Hous & $\begin{array}{l}\text { Cost, productivity, } \\
\text { employee satisfaction, } \\
\text { growth, state of } \\
\text { economy, firm } \\
\text { objectives }\end{array}$ & $\begin{array}{l}\text { Operational } \\
\text { effectiveness, } \\
\text { employee satisfaction, } \\
\text { productivity, state of } \\
\text { economy, firm } \\
\text { objectives }\end{array}$ & $\begin{array}{l}\text { Cost, productivity, } \\
\text { employee } \\
\text { satisfaction, growth, } \\
\text { state of economy, } \\
\text { firm objectives }\end{array}$ \\
\hline $\begin{array}{l}\text { Procurement } \\
\text { and tendering }\end{array}$ & $\begin{array}{l}\text { Management, } \\
\text { operational } \\
\text { effectiveness, degree } \\
\text { of competition, cost, } \\
\text { firm objectives }\end{array}$ & $\begin{array}{l}\text { Cost, management, } \\
\text { financial plan, firm } \\
\text { objectives }\end{array}$ & $\begin{array}{l}\text { Management, } \\
\text { operational } \\
\text { effectiveness, } \\
\text { degree of } \\
\text { competition, cost, } \\
\text { firm objectives }\end{array}$ \\
\hline Space planning & $\begin{array}{l}\text { Operational } \\
\text { effectiveness, } \\
\text { employee satisfaction, } \\
\text { productivity } \\
\text { Firm size, firm } \\
\text { objectives }\end{array}$ & $\begin{array}{l}\text { Employee satisfaction, } \\
\text { operational } \\
\text { effectiveness, } \\
\text { productivity, firm size, } \\
\text { firm objectives }\end{array}$ & $\begin{array}{l}\text { Firm size, employee } \\
\text { satisfaction, } \\
\text { operational } \\
\text { effectiveness, } \\
\text { productivity, firm } \\
\text { objectives }\end{array}$ \\
\hline
\end{tabular}


Table 3. Continued.

FM function Factors affecting business profitability

\begin{tabular}{llll}
\cline { 2 - 4 } & \multicolumn{1}{c}{ Case 1 } & \multicolumn{1}{c}{ Case 2 } & \multicolumn{1}{c}{ Case 3 } \\
\hline Risk & Management, & Cost, operational & Management, \\
management & operational & effectiveness, financial & operational \\
& effectiveness, degree & plan, employee & effectiveness, \\
& of competition, cost & satisfaction, & degree of \\
& ,firm objectives & $\begin{array}{l}\text { productivity, growth, } \\
\text { firm objectives }\end{array}$ & $\begin{array}{l}\text { competition, cost, } \\
\end{array}$ \\
& & &
\end{tabular}

\begin{tabular}{llll}
\hline $\begin{array}{l}\text { Quality } \\
\text { management }\end{array}$ & $\begin{array}{l}\text { Operational } \\
\text { effectiveness, cost, } \\
\text { productivity, } \\
\text { employee satisfaction, } \\
\text { growth, state of } \\
\text { economy, } \\
\text { competition, firm }\end{array}$ & $\begin{array}{l}\text { Productivity, } \\
\text { employee satisfaction, } \\
\text { crowth, degree of } \\
\text { economy, cost, firm } \\
\text { objectives }\end{array}$ & $\begin{array}{l}\text { Management, } \\
\text { operational } \\
\text { effectiveness, } \\
\text { degree of }\end{array}$ \\
$\begin{array}{ll}\text { competition, cost, } \\
\text { productivity, firm } \\
\text { objectives }\end{array}$
\end{tabular}

\begin{tabular}{llll}
\hline Emergency & Management & Employee Satisfaction, & Employee \\
Preparedness & Productivity, & Cost, Degree of & Satisfaction, \\
and disaster & Cost, Employee & Competition, & Cost, Degree of \\
management & Satisfaction, Firm & Operational & Competition, \\
& Objectives & Effectiveness, Firm & Productivity, Firm \\
& & Objectives & Objectives
\end{tabular}

Energy management and waste management. Through energy management, organizations can gain financial returns. Effective energy management is very much essential to reduce unnecessary energy costs of the building. Main objective of energy management has been stated as to maximize profits and minimize costs. On the other hand, waste management has been mentioned which leads to reducing the negative environmental impacts, achieve positive green public relationship, increase the good will of the hotel and obtain sustainability certificates. When obtaining such benefits, organisations could increase the efficiency of workers, productivity and finally can gain revenue by satisfying customers as well as workers.

Housekeeping and space planning. Housekeeping function has also been recognised which indirectly helps to increase the profits of hotel sector as it manages the facility with good housekeeping procedures. The way of increasing business profitability with this function has been mentioned by increasing customer satisfaction and goodwill. Further, as proper space planning with good interior designs result in customer satisfaction, 
respondents have identified this as an effective function to increase the business profitability.

Procurement and tendering. This function is important to analyse the external environment and to check the price fluctuations. If the price level is high, then the expenses also will be high. If there are high expenses the organization cannot gain profit. Thus, procurement has been identified as a major function of FM, which helps to enhance the profitability through the proper management.

Risk management and quality management. As every organisation are exposed number of hazards and unsafe conditions risk management is an important function to be made within any organisation. Risk management takes a major role in FM involving numerous strategies to overcome such unexpected events. Thus, respondents have identified this as an important service provided by FM to enhance business profitability. Besides, quality management in FM undertakes quality related services including retention of existing guests by exceeding their expectations, continuous quality improvement, employment, regular training and authorization of serviceoriented staff, search for top achieves through benchmarking, and finally detection of quality authorisation through the various schemes, as the ecolabels, ISO and the EU Foundation for Quality Management.

Emergency preparedness and disaster management. According to the results, by reducing the risks, the organization can feel free to do their works smoothly without any threats. As well as the hotel security guards should be trained and have good knowledge about the organisation to guide new guests. This will indirectly lead to increase in the productivity of the organization as well as growth of profitability. Hence, this function was highly appreciated by respondents as an important FM function to enhance business profitability.

\section{Conclusion}

The study captured a portrayal of FM value addition in enhancing business profitability in hotel industry. It is the common point of view that there is very usual relationship between FM profession practices and profitability of business. As a result, the role of FM ensures the smooth operation of organisations to enhance the business profitability, and thereby provides economically accepted value addition. As per the findings, all identified FM functions equally relate to all the profitability factors. Every function is ultimately leading to accomplish the goals and objectives of the organizations achieving business profitability, even though, there is a huge potential in hotel industry and the importance of FM is still hidden in Sri Lankan context. From the overall FM perspective, it can be concluded that there is a direct relationship and great impact of FM functions to profitability factors to enhance the business profitability through increasing the added value for the hotel sector in Sri Lanka. Thus, this study may help to determine the actual 
benefits of integrating FM functions to increase the added value of Sri Lankan hotel sector to increase profitability.

\section{References}

Amaratunga, D., Baldry, D., \& Sarshar, M. (2000). Assessment of facilities management performance - what next? Facilities, 18(1/2), 66-75. doi:10.1108/02632770010312187

Andrews, S. (2013). Hotel housekeeping a training manual. Tata McGraw-Hill Education.

Jensen, A. P., van der Voordt, T., Coenen, C., von Felten, D., Lindholm, L. A., Nielsen, B.S., . . . Pfenninger, M. (2012). In search for the added value of FM: what we know and what we need to learn. Facilities, 30(5/6), 199217. doi:10.1108/02632771211208486

Atkin, B., \& Brooks, A. (2005). Total facilities management. Oxford: Blackwell science Ltd.

Bagshaw, B. K., \& Peters, G. T. (2015). Facility management and organizational effectiveness of manufacturing firms in Rivers State Nigeria. European Journal of Business and Management, 7(26), 67-80.

Barrett, P., \& Baldry, D. (2003). Facilities management : Toward best practice. Osney Mead, Oxford, Ox: Blackwell Science.

Brown, A., Hinks, J., \& Sneddon, J. (2001). The facilities management role in new building procurement. Facilities, 19(3/4), 119-130. doi:10.1108/02632770110381667

Bontis, N., Janošević, S., \& Dženopoljac, V. (2015). Intellectual capital in Serbia's hotel industry. International Journal of Contemporary Hospitality Management, 27(6), 1365-1384. doi:10.1108/ijchm-12-2013-0541

Chotipanich, S. (2004). Positioning facility management. Facilities, 22(13/14), 364372.

Coenen, C., Alexander, K., \& Kot, H. (2013). Facilities management value dimensions from a demand perspective. Facilities, 11(4), 339-356. doi:10.1108/jfm-10-2012-0049

Durodola, O. D., Ayedun, C. A., \& Onipede, I. S. (2012). Assessment of the traits of facilities management key drivers in South-Western Nigerian Hotels.

Journal of Management and Sustainability, 2(2). doi:10.5539/jms.v2n2p163

Edwards, J. (2012). Applied facilities management for the hospitality industry. In Jensen, P. A., \& van der Voordt, T. (2015). How can FM Create Value to Organization: A critical review of papers from EuroFM Research Symposia 2013-2015. Gooimeer: European Facilities Management Network (EuroFM). doi:10.13140/RG.2.1.2361.8089

Jones, P., \& Lockwood, A. (1989). The Management of hotel Operations an innovative approach to the study of hotel management. London: Cassel.

Kasim, R., \& Hudson, J. (2006). FM as a social enterprise. Facilities, 24(7/8), 292-299. doi:10.1108/02632770610666143

McDonald, J. T. (1999). The determinants of firm profitability in Australian Manufacturing. Economic Record, 75(2), 115-126. doi:10.1111/j.14754932.1999.tb02440.x 
Myeda, N. E. (2012). The sphere of performance measurement in strategic facilities management. Journal of Facilities Management, 10(3). doi:10.1108/jfm.2012.30810caa.001

Padavano, K. R. (2005). Benchmarking strategies for gauging operational performance. Facilities, 3(2), 145-160. doi:10.1108/14725960510808455

Penny, W. (2012). The use of environmental management as a facilities management tool in the Macao hotel sector. Facilities, 25(7/8), 286-295. doi:10.1108/02632770710753325

Pitt, M., \& Goyal, S. (2004). Business continuity planning as a facilities engagement tool. Facilities, 22(3/4), 87-89. doi:10.1108/02632770410527824

Smith, A. (2011). How important is the physical workplace to engagement and productivity? Journal of Facilities Management, 9(2), 30. doi:10.1108/jfm.2011.30809baa.001

Vom Brocke, J., \& Grob, H. L. (2010). Profitability of business processes. Process Management, 421-446. doi:10.1007/978-3-642-15190-3_15

Yazdanfar, D. (2013). Profitability determinants among micro firms evidence from swedish data. International Journal of Managerial Finance, 9(2), 151160. doi:10.1108/17439131311307565 